\title{
Effect of top-dressed potassium fertilization on the yield and quality of cucumber
}

\section{Carla Verônica Corrêa, Aline Mendes de Sousa Gouveia, Bruno Novaes Menezes Martins, Natália de Brito Lima Lanna, Ana Emília Barbosa Tavares, Veridiana Zocoler Mendonça, Letícia Galhardo Jorge, Antonio Ismael Inácio Cardoso \& Regina Marta Evangelista}

To cite this article: Carla Verônica Corrêa, Aline Mendes de Sousa Gouveia, Bruno Novaes Menezes Martins, Natália de Brito Lima Lanna, Ana Emília Barbosa Tavares, Veridiana Zocoler Mendonça, Letícia Galhardo Jorge, Antonio Ismael Inácio Cardoso \& Regina Marta Evangelista (2018) Effect of top-dressed potassium fertilization on the yield and quality of cucumber, Journal of Plant Nutrition, 41:10, 1345-1350, DOI: 10.1080/01904167.2018.1447580

To link to this article: https://doi.org/10.1080/01904167.2018.1447580

\section{曲 Published online: 19 Mar 2018.}

\section{Submit your article to this journal ๔}

山 Article views: 63

View Crossmark data ¿

4

Citing articles: 1 View citing articles $\square$ 


\title{
Effect of top-dressed potassium fertilization on the yield and quality of cucumber
}

\author{
Carla Verônica Corrêa ${ }^{\mathrm{a}}$, Aline Mendes de Sousa Gouveia ${ }^{\mathrm{a}}$, Bruno Novaes Menezes Martins ${ }^{\mathrm{a}}$, \\ Natália de Brito Lima Lanna ${ }^{\mathrm{a}}$, Ana Emília Barbosa Tavares ${ }^{\mathrm{a}}$, Veridiana Zocoler Mendonçab, \\ Letícia Galhardo Jorge ${ }^{c}$, Antonio Ismael Inácio Cardoso ${ }^{a}$, and Regina Marta Evangelista ${ }^{a}$
}

${ }^{a}$ Departament of Horticulture, São Paulo State University, Botucatu, Brazil; ${ }^{b}$ Departament of Energy in Agriculture, São Paulo State University, Botucatu, Brazil; ' Institute of Bioscience, São Paulo State University, Botucatu, Brazil

\begin{abstract}
The current study aimed to evaluate the effect of top-dressed potassium (K) application on the production of hybrid cucumber "Sapphire." The experimental design was a randomized complete block, with five blocks of $0.80 \times 0.40 \mathrm{~m}^{2}$ each and eight replicate plants per block. The five fertilization rates of $\mathrm{K}$ used were $0,45,90,135$, and $180 \mathrm{~kg} \mathrm{~K}_{2} \mathrm{O} \mathrm{ha}^{-1}$. Data collection consisted of the estimation of fruit diameter, fruits length, fruit fresh and dry weights, the number of fruits per plant, and the weight of fruits per plant. The number of fruits per hectare and the fruit fresh weight per hectare were calculated. Fruit tissue was analyzed for determination of macronutrient concentrations, $\mathrm{pH}$, titratable acidity, soluble solids, sugar contents, and protein content. The data were statistically analyzed using regression analysis and analysis of variance (ANOVA). There was a significant effect of the fertilization rate of $K$ on fruit diameter, fruit fresh and dry weights, macronutrients concentrations in fruits, titratable acidity, soluble solids, and reducing sugars. A quadratic equation was adjusted for the number of fruits per plant and per hectare; fruit yield per plant and per hectare, with maximum top-dressing doses, was estimated to be between 60 and $95 \mathrm{~kg}$ $\mathrm{K}_{2} \mathrm{O} \mathrm{ha}{ }^{-1}$. A linear increase was obtained in the $\mathrm{pH}$. An increase in the $\mathrm{K}$ fertilization rate caused a linear decrease in the fruit length.
\end{abstract}

\section{ARTICLE HISTORY}

Received 27 October 2016

Accepted 29 November 2017

\section{KEYWORDS}

Cucumis sativus; fertilizer; macronutrient; postharvest productivity

\section{Introduction}

Cucumber (Cucumis sativus) is among the most widely cultivated cucurbits in Brazil. This crop has a great economic and social importance as it provides employment to many people. It belongs to the same family of pumpkin, melon, watermelon, chayote, and gherkin. Cucumber originally comes from India, where it grows in tropical climate and under high temperature conditions. Its fruit has a considerable amount of vitamins and minerals, including calcium, phosphorus, and iron (Filgueira 2008).

For this crop, Raij et al. (1997) recommended a fertilization rate of 40, 200-400, 100-200 $\mathrm{kg} \mathrm{ha}^{-1}$ of nitrogen $(\mathrm{N}), \mathrm{P}_{2} \mathrm{O}_{5}$, and $\mathrm{K}_{2} \mathrm{O}$, respectively. They also recommended top-dressed $\mathrm{N}$ and potassium $(\mathrm{K})$ fertilization rates of respectively $100-150 \mathrm{~kg} \mathrm{~N}^{-1}$ and $60-120 \mathrm{~kg} \mathrm{~K}_{2} \mathrm{O} \mathrm{ha}^{-1}$, splitting $\mathrm{K}$ fertilization into three applications (i.e., 15, 30, and 45 days after transplantation).

Cucumber crops generally require a high supply of $\mathrm{K}$, for it being the most translocated macronutrient to the fruits (Marschener 2011). K plays an important role in physiological and biochemical plant functions, such as photosynthesis, osmotic regulation, enzyme activation (Marschener 2011), in

CONTACT Carla Verônica Corrêa crcorrea1509@gmail.com @ Departamento de Horticultura, Universidade Estadual Paulista, Botucatu, São Paulo, Brazil.

○ 2018 Taylor \& Francis Group, LLC 
balancing $\mathrm{N}$ application, in balancing the vegetative and reproductive growth of the plant, and in improving the fruit quality to a longer shelf life, which lead to a better market value (Filgueira 2008). For growing plants, about $20-50 \mathrm{~g} \mathrm{~K} \mathrm{~kg}^{-1}$ is necessary for an optimum accumulation of the dry matter of the vegetative parts of the plant as well as that of the fruits and the tubers. However, plants have the ability to uptake greater amounts of K to meet their needs, i.e., "luxury consumption"; it does not mean that the yield will be increased (Fernandes 2006).

The quality of a vegetable must take into account both intrinsic (product) and extrinsic traits (product perception within handling system); therefore, products need to be aimed at maintaining quality throughout all the development stages: maturity, harvest, and postharvest (Chitarra and Chitarra 2005). However, a few studies correlated management practices, such as fertilization, with the physicochemical characteristics and quality parameters of vegetables. Araújo (2011) observed no influence of $\mathrm{K}$ on production, macronutrient exports by fruits, and the other traits of zucchini.

Given all the above, the current research aimed to evaluate the effect of $\mathrm{K}$ topdressing on the yield and fruit quality of cucumber.

\section{Materials and methods}

The experiment was carried out at Sao Manuel Experimental Farm, Botucatu School of Agronomy, UNESP $\left(22^{\circ} 46^{\prime} \mathrm{S}, 48^{\circ} 34^{\prime} \mathrm{W} ; 740 \mathrm{~m}\right.$ altitude). The mean annual temperature is $21^{\circ} \mathrm{C}$, and the mean annual rainfall of São Manuel is 1,445 mm (Cunha and Martins 2009).

The soil is classified as Dystrophic Red Latosol (oxisoil) (EMBRAPA 2006). Prior to the experiment, soil samples were collected at a depth of $0-20 \mathrm{~cm}$ to determine their chemical properties: $\mathrm{pH}$ in $\mathrm{CaCl}_{2}$, 5.8; organic matter (O.M.), $9 \mathrm{~g} \mathrm{dm}^{-3}$; Presin, $35 \mathrm{mg} \mathrm{dm}^{-3} ; \mathrm{H}+\mathrm{Al}, 15 \mathrm{mmol}_{\mathrm{c}} \mathrm{dm}^{-3} ; \mathrm{K}, 1.9 \mathrm{mmol}_{\mathrm{c}}$ $\mathrm{dm}^{-3}$; Ca, $28 \mathrm{mmol}_{\mathrm{c}} \mathrm{dm}^{-3} ; \mathrm{Mg}, 10 \mathrm{mmol}_{\mathrm{c}} \mathrm{dm}^{-3}$; SB, $40 \mathrm{mmol}_{\mathrm{c}} \mathrm{dm}^{-3}$; CTC, $55 \mathrm{mmol}_{\mathrm{c}} \mathrm{dm}^{-3}$; and V\%, 72. Considering the soil classification, $40 \mathrm{~kg} \mathrm{~N}^{-1}, 300 \mathrm{~kg} \mathrm{P}_{2} \mathrm{O}_{5} \mathrm{ha}^{-1}, 150 \mathrm{~kg} \mathrm{~K}_{2} \mathrm{O} \mathrm{ha}^{-1}$, and $4 \mathrm{~kg}$ $\mathrm{m}^{-2}$ of Provaso ${ }^{\circledR}$ organic compost were applied at the time of planting, according to the methodology described by Raij et al. (1997).

The experimental design was a randomized complete block, with five blocks of $0.80 \times 0.40 \mathrm{~m}^{2}$ each and eight replicate plants per block. Five fertilization rates of $\mathrm{K}\left(0,45,90,135\right.$, and $\left.180 \mathrm{~kg} \mathrm{~K}_{2} \mathrm{O} \mathrm{ha}{ }^{-1}\right)$ were used on the cucumber plants. The hybrid Sapphire (hick type) was acquired from Sakata ${ }^{\circledR}$ company.

Seeds were planted on 3 October 2014, in polypropylene trays of 162 cells in a greenhouse. Plants were transplanted to the fields on 13 October 2014, when they achieved a real leaf stage. The spacing between the rows was $0.80 \mathrm{~m}$ and between the plants within a row was $0.40 \mathrm{~m}$. Sprinkler irrigation was used along with plastic mulch, which covered the rows, to control weed.

According to the methodology described by Raij et al. (1997), top-dressing fertilization was used in three split doses. Plants were fertilized 15 days after transplantation, with $\mathrm{K}$ supplied as potassium chloride and $\mathrm{N}$ as urea $\left(125 \mathrm{~kg} \mathrm{~N} \mathrm{ha}^{-1}\right)$. $\mathrm{K}$ was applied as a cover in accordance with the fertilization rates of $0,45,90,135$, and $180 \mathrm{~kg} \mathrm{~K}_{2} \mathrm{O} \mathrm{ha}^{-1}$.

Data collection consisted of the number of fruits per plant and per hectare, fruit fresh and dry weights, and fruit diameter and length. To obtain the dry weight of a fruit, samples were collected and washed. Then, the samples were placed into paper bags, identified, and dried using a forced-air-circulation oven at $65^{\circ} \mathrm{C}$ until a constant weight was achieved in about $48 \mathrm{hr}$ (Malavolta, Vitti, and Oliveira 1997). Subsequently, the dry weight of each cucumber was measured using an analytical balance.

To estimate the nutrient content $(\mathrm{N}, \mathrm{P}, \mathrm{K}, \mathrm{Ca}, \mathrm{Mg}$, and $\mathrm{S})$, two fruits per plot were sampled and ground using a Wiley mill. Two digestion methods were used: sulphuric acid was to determine $\mathrm{N}$ content, and nitric-perchloric acid was to determine $\mathrm{P}, \mathrm{K}, \mathrm{Ca}, \mathrm{Mg}$, and $\mathrm{S}$ contents, according to the methodology described by Malavolta, Vitti, and Oliveira (1997).

With regard to the chemical analyses, the concentration of $\mathrm{N}, \mathrm{P}, \mathrm{K}, \mathrm{Ca}, \mathrm{Mg}$, and $\mathrm{S}$ was read in $\mathrm{g}$ $\mathrm{kg}^{-1}$. The amount of nutrient extracted (in $\mathrm{g}$ ) was obtained by multiplying the concentration of each nutrient by the sample dry matter. 
In order to examine the postharvest physicochemical properties, fruits were transported to Fruits and Vegetables Postharvest Laboratory, Horticulture Department, Botucatu, Brazil. Two fruits per plot were washed in deionised water to evaluate titratable acidity, soluble solids, $\mathrm{pH}$, reducing sugars, and protein. Titratable acidity was determined by titrating $5 \mathrm{~g}$ of homogenized slurry in $100 \mathrm{~mL}$ of distilled water against freshly prepared $0.1 \mathrm{~N}$ sodium hydroxide, using $1 \%$ phenolphthalein as indicator, according to Adolfo Lutz Institute (Agência Nacional de Vigilância Sanitária 2005). Soluble solids $\left(\mathrm{SS} / \mathrm{Brix}^{\circ}\right)$ were determined by placing two drops of macerated juice for $1 \mathrm{~min}$ on the prism surface of an electronic refractometer (Atago, PR32 model), according to the recommendations made by the Association of Official Analytical Chemists (2005). The $\mathrm{pH}$ was directly determined on samples using a potentiometer (Digital DMPH-2), according to the methodology described by Adolfo Lutz Institute (Agência Nacional de Vigilância Sanitária 2005). The levels of reducing sugars were determined by the method described by Somogyi and adapted by Nelson (1944); the results were expressed as the percentage of glucose. The protein content was determined by the Kjeldahl crude protein method, which requires a conversion factor of 6.25 (Method 920.87 of Association of Analytical Chemists 2005).

All data were statistically analyzed using regression analysis and ANOVA using software statistics Sisvar (Sisvar, Schneider-Electric, Rueil-Malmaison, France).

\section{Results and discussion}

There were no significant effects of $\mathrm{K}$ fertilization rate on fruit diameter, fruit fresh weight, or fruit dry weight. On average, fruit diameter, fruit fresh weight, and fruit dry weight were $53.8 \mathrm{~mm}, 270.2 \mathrm{~g}$, and $8.2 \mathrm{~g}$, respectively. Our results are similar to those of Araújo (2011), who worked on bush zucchini and to those of Corrêa, Cardoso, and Rodrigues Claúdio (2013), who worked on cabbage.

There was, however, a significant effect of $\mathrm{K}$ fertilization rate on the fruit length. Our results indicate that an increase in the $\mathrm{K}$ fertilization rate caused a linear decrease in the fruit length (Figure 1). These results are contradictory to those reported on cabbage by Corrêa, Cardoso, and Rodrigues Claúdio (2013) and on carrots by Zanfirov et al. (2012); therefore, the application of K topdressing did not influence the cabbage head height and carrot root length in these studies.

A quadratic function was observed for the number of fruits per plants, with a maximum estimated average of 5.8 fruits at a $\mathrm{K}$ dose of $75 \mathrm{~kg} \mathrm{ha}^{-1}$. This pattern also occurred in the number of fruits per hectare, with a maximum estimated average of 187289.6 fruits at a $\mathrm{K}$ dose of $83.9 \mathrm{~kg} \mathrm{ha}^{-1}$, and the yield per plant had a maximum estimated average of $1.6 \mathrm{~kg}$ at a $\mathrm{K}$ dose of $85.7 \mathrm{~kg} \mathrm{ha}^{-1}$. Also, a quadratic adjustment was obtained for maximum yield, with an estimated average of $52.6 \mathrm{t} \mathrm{ha}^{-1}$ at a $\mathrm{K}$ dose of $92.5 \mathrm{~kg} \mathrm{ha}^{-1}$ (Figure 1). Thus, the increase in cucumber yield was found at a dose of 70-95 kg ha-1, which is in accordance with the recommended dose range by Raij et al. (1997), i.e., top-dressing doses from 60 to $120 \mathrm{~kg} \mathrm{ha}^{-1}$.

The increase in the production was contrary to those found in the literature for $\mathrm{K}$ fertilization on other crops, such as in clump of zucchini by Araújo (2011), pumpkin by Araújo, Quadros, and Cardoso (2012), cabbage by Corrêa, Cardoso, and Rodrigues Claúdio (2013), and carrot by Zanfirov et al. (2012). Thus, the response to a particular nutrient depends on several factors, such as species and cultivar, which shows the importance of specific studies on fertilizers.

With regard to the number of fruits and yield per plant, they were lower than those found by Salata (2010), with an average of 13.5 fruits and 1,436 g per plant under staked and protected environmental conditions. However, it should be noted that plants were grown under field conditions in the current study; therefore, creepers tend to reduce production due to the higher incidence of diseases.

There were no statistical significance for titratable acidity, soluble solids, and reducing sugars, with average values of $0.151 \%$ citric acid, $3.3^{\circ}$ Brix, and $1.67 \%$, respectively. These results corroborate those found by Grangeiro and Cecilio Filho (2004), who evaluated the quality of watermelon fruits to sources and doses of $\mathrm{K}$ during planting; they found that the applied rates (i.e., $50-300 \mathrm{~kg} \mathrm{~K}_{2} \mathrm{O} \mathrm{ha}{ }^{-1}$ ) did not affect the titratable acidity. In plant tissues, organic acids are associated with their $\mathrm{K}$ salts buffer system that regulates enzyme activities (Chitarra and Chitarra 2005). Furthermore, whenever there is a high 

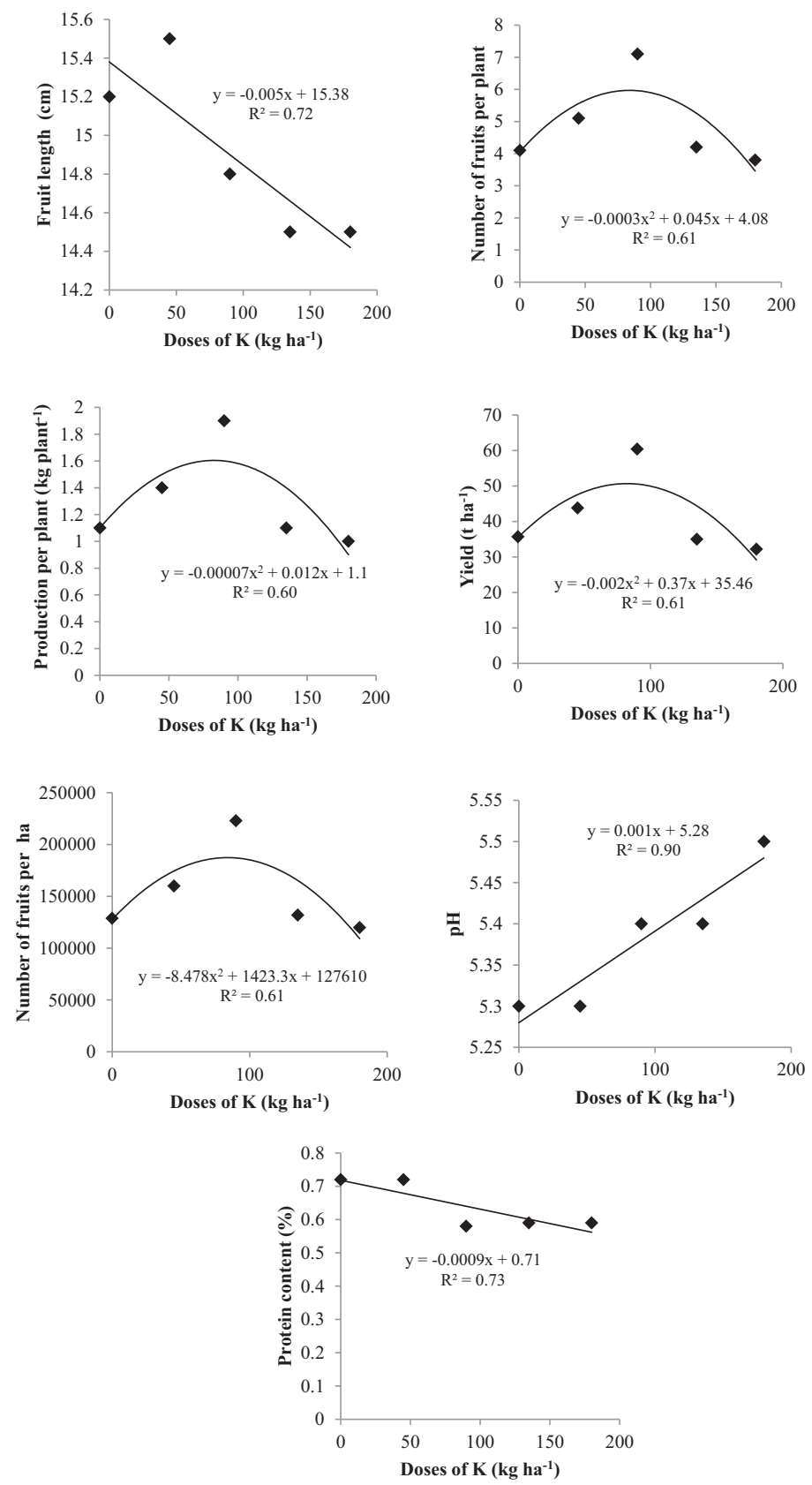

Figure 1. Fruit length, number of fruits per plant, production $(\mathrm{g})$ per plant, yield $(t)$, protein content (\%) of cucumber fruits with doses of $\mathrm{K}$ topdressing.

concentration of $\mathrm{K}$ in the cell, there is also a need of organic acids to ensure that an ion balance is maintained (Silva et al. 2006). Araujo (2011) did not found any significant effect of K topdressing on soluble solids. Regardless of the treatment, the fruits showed average values of approx. $4.94^{\circ}$ Brix. The soluble solids correspond to compounds dissolved in the water of the food.

Within the fruits, accumulated sugars are among the main constituents; consequently, the higher the total solid content, the higher the sugar content in fruits (Chitarra and Chitarra 2005). However, Costa et al. (2004) concluded that $\mathrm{K}$ concentrations up to $66 \mathrm{mg} \mathrm{L}^{-1}$ did not affect the soluble solids content and titratable acidity in melon fruits. 
Reducing sugars content is not more than the concentration of glucose and fructose within the fruit. Their concentrations increased according to the ripening stage of the fruit. Since cucumbers are harvested during an immature stage, there are no accumulated sugars, and so it did not present any significant difference. Similar results were observed in bush zucchini by Araújo (2011), when harvested at an immature stage, in order to assess the K topdressing.

For the $\mathrm{pH}$, a linear increase in the rates of $\mathrm{K}$ topdressing was observed (Figure 1). Vázquez et al. (2005) also obtained a linear increase in the $\mathrm{pH}$ of melon fruits at different doses of $\mathrm{K}$ by fertigation. This pattern was also observed in K topdressing on bush zucchini by Araújo (2011).

A linear decrease was observed for protein at increasing doses of $\mathrm{K}$ (Figure 1). However, there are some literature reports on other species, showing the association of cucumber's protein content with $\mathrm{K}$ fertilization. Additionally, these studies have shown that changes in protein levels are more related to genetic factors than nutrition. Fernandes et al. (2011), while working with potato crop, did not observe any difference in tuber protein by applying phosphorus. $\mathrm{K}$ is vital to many plant processes, as activates many enzyme systems during photosynthesis, respiration, and especially protein synthesis. Besides that, $\mathrm{K}$ also acts on the opening and closing of stomata, phloem transport, osmoregulation, and cation-anion balance (Marschener 2011).

Regarding macronutrients export by fruits, there was no statistical significance for cucumber fruits due to the $\mathrm{K}$ doses. The average values for $\mathrm{N}, \mathrm{P}, \mathrm{K}, \mathrm{Ca}, \mathrm{Mg}$, and $\mathrm{S}$ were 233.3, 72.9, 523.2, 57.4, 31.5, and $19.9 \mathrm{mg}$ fruit $^{-1}$, respectively. The same behavior was observed by Araújo (2011), who evaluated the nutrients export with $\mathrm{K}$ doses on bush zucchini. In general, the current experiment did not show a tendency to export more nutrients than necessary. Although there was an increasing amount of available $\mathrm{K}$, this macronutrient export did not increase; consequently, there was no luxury consumption, as described by Brady (1989). Therefore, the descending order of macronutrient export by fruits was $\mathrm{K}>$ $\mathrm{N}>\mathrm{P}>\mathrm{Ca}>\mathrm{Mg}>\mathrm{S}$.

Studying nutrient export allows applying correctly the fertilizer according to crop nutritional needs. Also, determining the correct nutrient dose contributes to the development of a more sustainable agriculture, as it prevents deficiencies or excesses that can hinder productivity and fruit quality, while reducing environmental impacts by cutting down costs.

\section{Conclusions}

There were some statistical differences in diameter, fruits fresh and dry matter weights, nutrients export, titratable acidity, soluble solids, and reducing sugars. Also, there was a quadratic adjustment for the number of fruits per plant and per hectare, and fruit yield per plant and per hectare at 70-95 kg $\mathrm{K}_{2} \mathrm{O} \mathrm{ha}^{-1}$. For the $\mathrm{pH}$, a linear increase was obtained, but a linear decrease was obtained in protein content due to the increase in $\mathrm{K}$. The $\mathrm{K}$ levels did not influence the macronutrients uptake.

\section{Funding}

The authors would like to thank Co-ordination for the Improvement of Higher Education Personnel (CAPES), National Council for Scientific and Technological Development (CNPq), and São Paulo Research Foundation (FAPESP) (Grant 2016/13915-5) for granting scholarship to this study.

\section{References}

Agência Nacional de Vigilância Sanitária. 2005. Métodos fisico-químícos para análise de alimentos. 4th ed. Brasília, DF: Ministério da Saúde.

Araújo, H. S. 2011. Doses de potássio em cobertura na produção e qualidade de frutos de abobrinha-de-moita. Botucatu, SP: Faculdade de Ciências Agronômicas, Universidade Estadual Paulista.

Araújo, H. S., B. R. Quadros, A. I. I. Cardoso, and C. V. Corrêa. 2012. Doses de potássio em cobertura na cultura da abóbora. Pesquisa Agropecuária Tropical 42:469-75.

Association of Official Analytical Chemists. 2005. Official methods of analysis of the association of official analytical chemistry. 18th ed. Washington, DC: Association of Official Analytical Chemists. 
Brady, N. C. 1989. Natureza e propriedades do solo. 7th ed. Rio de Janeiro, RJ: Freitas Bastos.

Chitarra, M. I. F. and A. B. Chitarra. 2005. Pós-colheita de frutos e hortaliças. 2nd ed. Lavras, MG: ESAL/FAEPE.

Corrêa, C. V., A. I. I. Cardoso, and M. T. Rodrigues Claúdio. 2013. Produção de repolho em função de doses e fontes de potássio em cobertura. Semina 34:2129-38.

Costa, C. C., A. B. Cecilio Filho, R. L. Cavarianni, and J. C. Barbosa. 2004. Concentração de potássio na solução nutritiva e a qualidade e número de frutos de melão por planta em hidroponia. Ciência Rural 34 (3):731-36. doi:10.1590/S010384782004000300012 .

Cunha, A. R. and D. Martins. 2009. Classificação climática para os municípios de Botucatu e São Manuel, SP. Irriga 14:111. doi:10.15809/irriga.2009v14n1p01.

Empresa Brasileira de Pesquisa Agropecuária (EMBRAPA). 2006. Sistema brasileiro de classificação dos solos. Brasília, DF: EMBRAPA.

Fernandes, A. M., R. P. Soratto, R. M. Evangelista, B. L. Silva, and G. D. Souza-Schlick. 2011. Produtividade e esverdeamento pós-colheita de tubérculos de cultivares de batata produzidos na safra de inverno. Revista Ciência Agronômica 42:502-8. doi:10.1590/S1806-66902011000200033.

Fernandes, M. S. 2006. Nutrição mineral das plantas. Viçosa, MG: Sociedade Brasileira de Ciência do Solo.

Filgueira, F. A. R. 2008. Novo manual de olericultura. 3rd ed. Viçosa, MG: UFV.

Grangeiro, L. C. and A. B. Cecílio Filho. 2004. Qualidade de frutos de melancia sem sementes em função de fontes e doses de potássio. Ciênciae Agrotecnologia 28:570-6. doi:10.1590/S1413-70542004000300012.

Malavolta, E., G. C. Vitti, and S. A. Oliveira. 1997. Avaliação do estado nutricional das plantas, princípios e aplicações. 2 nd ed. Piracicaba, SP: Potafós.

Marschner, H. 2011. Mineral Nutrition of Higher Plants. 3rd ed. New York, NY: Academic Press.

Nelson, N. 1944. A photometric adaptation of Somogyi method for determination of glucose. Journal of Biological Chemistry 153:375-80.

Raij, B. V., J. C. Andrade, H. Cantarella, and J. A. Quaggio. 1997. Análise química para avaliação da fertilidade de solos tropicais. Campinas, SP: Instituto Agronômico.

Salata, A. C. 2010. Produção e nutrição de pepino enxertado e não enxertado em ambiente com nematoides-das-galhas. Botucatu, SP: Faculdade de Ciências Agronômicas, Universidade Estadual Paulista.

Silva, R. A., L. F. Cavalcante, J. S Holanda, W. E. Pereira, M. F. Mouras, and M. Ferreira Neto. 2006. Qualidade de frutos de coqueiro - anão verde fertirrigado com nitrogênio e potássio. Revista Brasileira de Fruticultura 28:310-13. doi:10.1590/S0100-29452006000200035.

Vásquez, M. A. N., M. V. Folegatti, N. S. Dias, and V. F. Sousa. 2005. Qualidade pós-colheita de frutos de meloeiro fertirrigado com diferentes doses de potássio e laminas de irrigação. Revista brasileira de engenharia agrícola e ambiental 9:199-204. doi:10.1590/S1415-43662005000200008.

Zanfirov, C. A., C. V. Corrêa, M. G. Carpanetti, and A. I. I. Cardoso. 2012. Produção de cenoura em função das doses de potássio em cobertura. Horticultura Brasileira 30:747-50. doi:10.1590/S0102-05362012000400030. 